\title{
The Reconceptualization of Academic Discourse as a Professional Prac- tice in the Digital Age: A Critical Genre Analysis of TED Talks
}

\begin{abstract}
This paper explores how academic discourse is reconceptualized as a professional practice via the web-mediated genre of TED talks (Technology, Entertainment and Design), popularizing speeches delivered by experts in fields that range from the 'hard' disciplines to the social sciences and the humanities. More precisely, this study compares two corpora of academic spoken discourse, i.e., a corpus of transcribed TED talks given by academics (TED_ac) and a corpus of university lecture transcripts (MICASE_lect) drawn from the Michigan Corpus of Academic Spoken English (MICASE) to understand how academics' communicative purposes differ in these two settings. Drawing on the theoretical frameworks of Critical Genre Analysis (Bhatia 2012) and Discourse Analysis (Goffman 1981; Fairclough 1989; Pennycook 1994; De Fina 1995; Benwell/Stokoe 2006; De Fina 2006), the present study sets out to investigate ways in which academics make use of language on the TED stage to achieve their "private intentions" as professionals (Bhatia 2012), e.g., building up their identity as experts as well as promoting their research and scholarship, rather than training a group of novices in their discipline or merely informing mass audiences. To this end, consideration is given to the distribution of first and second person pronouns in the two pragmatic contexts under investigation. Special emphasis is placed on referents and discourse functions of the pronoun we, which is significantly more frequent in TED_ac than in MICASE_lect. Despite its language-centered approach, this study has a marked sociological intent, as it casts light on an instance of academic discourse seen as an example of "professional practice" embedded in the wider context of a "professional culture" (Bhatia 2012).
\end{abstract}

\section{Introduction}

This study is situated within the research field of English for Specific Purposes (ESP) and draws on the theoretical frameworks of Critical Genre Analysis (CGA) (Bhatia 2007, 2008, 2010, 2012) and Discourse Analysis (DA) (Goffman 1981; Fairclough 1989; Pennycook 1994; De Fina 1995; Benwell/Stokoe 2006; De Fina et al. 2006) as well as on the methods of corpus linguistics (Baker 2006; Baker et al. 2008) to explore the way in which academic discourse is reconceptualized and recontextualized as a professional practice via the Web. More specifically, the present study sets out to investigate how academics pursue their professional objectives by means of the webmediated genre of TED ${ }^{1}$ talks, popularizing speeches delivered by experts in different fields and which touch upon a variety of topics, ranging from the 'hard' disciplines to the social sciences and the humanities.

The theoretical approach of CGA results from a gradual shift in focus in genre theory from pedagogic applications within ESP (Swales 1990; 2004) to the investigation of the "world of professions" (Bhatia 1993; 2004). Conceiving of genres as configurations of text-internal and textexternal resources, CGA gives prominence to the study of the contexts in which professional practices take place and regards the role and function of "interdiscursivity" (Fairclough 1992) in the development of genres as essential. Unlike intertextuality (Kristeva 1980, Foucault 1981; Bakhtin

1 The acronym stands for Technology, Entertainment and Design.

\footnotetext{
* Antonio Compagnone former PhD fellow at the University of Naples "Federico II" Department of Political Science compagnone.antonio@gmail.com
} 
1986; Fairclough 1992, 1995; Candlin/Maley 1997), which is based on appropriations across text-internal resources (e.g. use of quotations, lexis), interdiscursivity is based on appropriations "across three kinds of contextual and other text-external resources: genres, professional practices and professional cultures" (Bhatia 2012: 24). These forms of appropriation can be illustrated by "various forms of hybrids, such as mixing, embedding and bending of genres" (Bhatia 2012: 25). In a recent paper, Bhatia (2010) discusses three examples of interdiscursivity: (a) the combination of accounting discourse and public relation discourse within the genre of the corporate annual report, (b) the colonization of arbitration practices by litigation, and (c) the colonization of fundraising discursive practices by the culture of marketing and advertising. It is through the analysis of forms of appropriation like (a), (b) and (c) that CGA attempts to achieve its 'critical' goal, i.e. "demystifying professional practice through the medium of genres" and observing "how professional writers use the language to achieve the objectives of their professions" (Bhatia 2012: 23-24).

It is against this backdrop that the present study uses CGA to examine online academic discourse, placing emphasis on a genre, i.e. TED talks, where informational and promotional aims overlap. In other words, consideration is given to the ways in which academics make use of language on the TED stage to convey their "private intentions" (Bhatia 2012) - i.e. to build up their expert identity and promote their research - besides informing lay audiences. From this perspective, the present study aims to broaden the research application of CGA, which so far has mainly centered on the investigation of professional discursive performance in legal and corporate contexts (e.g. Bhatia 2007, 2008, 2010; Bhatia et al. 2008, 2009, 2010, 2012a, 2012b).

Academic discourse has a pivotal role in the processes of knowledge creation, legitimation and dissemination within society. As Hyland (2009: 2) observes:

\begin{abstract}
[...] beyond the university, the languages of the academy have quietly begun to insert themselves into every cranny of our lives in the West, colonizing the discourses of technocracy, bureaucracy, entertainment and advertising. Almost unnoticed, academic discourses have reshaped our entire world view, becoming the dominant mode for interpreting reality and our own existence. We find traces of it not just in popular science periodicals but in the Sunday broadsheets and the TV documentary, it is the language of the pharmaceutical bottle and the toothpaste advertisement, the psychotherapist and the recycling leaflet. It is the carrier of expertise and prestige - the badge of those who possess knowledge and of those who wish to.
\end{abstract}

An important consequence of the colonization of today's society by academic discourse is the fact that the production of scientific knowledge has become highly contextualized, in the sense that it is contingent upon a constant 'dialogue' between science and society. As Nowotny et al. (2001: 52-53) put it, society "speaks back to science" and manifests its "expectations about science's ability to provide useful answers to an ever increasing range of societal problems". Contextualization undermines the autonomy of science as it makes the notion of 'expertise' a value which experts need to negotiate with the rest of society. As a matter of fact, in the framework of the contemporary "knowledge-based economy" (OECD 1996), to keep their 'social prestige' and, above all, to obtain financial support, academics are increasingly required to establish direct contact not only with the lay public but also with fund providers (be it private or public institutions) and persuade them of the worthiness, usefulness and the applicability of academic research to everyday life. As a result, academics increasingly draw on the channels offered by the Web to present themselves as reliable sources of information, while popularizing and promoting their research.

It is on the basis of these premises that the present paper intends to explore ways in which academic TED speakers present themselves discursively on the TED stage. To this end, special consideration in this paper is given to person deixis (Grundy 2008) - a salient topic in the study of the discursive construction of identity (see, e.g., Goffman 1981; Fairclough 1989; Pennycook 1994; De Fina 1995; Benwell/Stokoe 2006; De Fina et al. 2006). More specifically, on the basis of previous research on the use of the pronoun we in the genre of the university lecture (Rounds 1987a, 1987b, Fortanet 2004), a contrastive corpus-based analysis is carried out by comparing use and distribution of we in the setting of the university classroom to those in academic TED talks (see 
section 3). Differences in the use of we in these two settings are thought to highlight differences in the communicative purposes of academics speaking at TED as opposed to academics speaking in the university classroom and allow us to make inferences about the reconceptualization of academic discourse as a professional practice via the popularizing genre of TED talks.

Previous research on popularization discourse has focused on linguistic strategies employed by experts to simplify, organize and illustrate specialized content (see, e.g., Nwogu 1991; Hyland 2010; Calsamiglia/López Ferrero 2003; Ciapuscio 2003; Garzone 2006; Bamford 2014; Bondi 2014; Garzone 2014), placing emphasis on aspects such as content management and reformulation. Consideration has also been given to the negotiation of expert/non-expert roles during faceto-face communicative exchanges (e.g. doctor-patient roles) (Gülich 2003), as well as on the coconstruction of knowledge via expert/non-expert interactions enabled by online forums (e.g. medical forums) (Anesa/Fage-Butler 2015). However, less attention has been paid to the ways in which experts draw on popularizing genres to convey their "private intentions" as professionals (Bhatia 2012), rather than merely communicate a 'simplified' version of science to inform mass audiences.

In the light of the above, the present study moves beyond the simplistic view of popularization as "writing [or speaking] that makes new or complex research and ideas accessible to nonspecialists" (Luey 2010: 5) and attempts to show that popularization discourse is a more complex phenomenon of recontextualization (Calsamiglia 2003; Calsamiglia/van Dijk 2004), which involves processes of identity (re)construction as well as of reconceptualization of professional practices.

In spite of its language-centered approach, this study has a marked sociological intent and its aim is to provide empirical evidence to show that TED talks constitute a new pragmatic setting within which practices of knowledge dissemination evolve and get 'contaminated' by other discursive practices according to the conventions of today's "knowledge-based economy" (OECD 1996) as well as to the norms of a "professional culture" (Bhatia 2007; 2008; 2010; 2012).

\section{TED talks: a new popularizing genre}

TED started out in 1984 as a conference gathering experts from three main fields: technology, entertainment and design. Under the management of the Sapling Foundation - a non-profit organization founded by the new-media entrepreneur Chris Anderson - the TED project has expanded remarkably, giving voice to experts and professionals from a larger number of fields. In 2007, the official TED website was launched, making the TED format known worldwide and emphasizing its popularizing intent under the motto "ideas worth spreading".

However, TED talks have only recently started to stimulate the interest of discourse analysts (see, e.g., Caliendo 2014a; Caliendo/Compagnone 2014; Compagnone 2014; Scotto di Carlo 2014). In her study, Caliendo acknowledges the novelty of this format and emphasizes its "discursive hybridity" (2014b: 113), pointing out the fact that TED talks lie at the intersection of a number of genre types, e.g. university lectures, newspaper articles, conference presentations and TV science programmes, mixing different semiotic modes, i.e. spoken, written, video and audio. From this point of view, TED talks provide a clear example of the way in which web-mediated popularization discourse has spurred the emergence of new genres, which result from the contamination of different discursive and professional practices and purposes (e.g. informational, promotional and providing entertainment).

Against this background, exploring TED talks was seen as useful for contributing to theoretical understanding relating to popularization discourse and, from a wider perspective, the critical analysis of genre, with special focus on spoken academic discourse.

\section{Corpus and methods}

TED talks are aimed at multiple audiences, in that a TED talk is both (a) a live communicative event, where a speaker addresses a group of co-present participants, and (b) a recorded speech 
event, embedded and recontextualized in the framework of a website accessible by users worldwide $^{2}$. In addition, TED talks (and the TED website) combine different semiotic modes (i.e. spoken, written, audio and video) and can be explored from different perspectives.

However, for the purposes of this study, a corpus-based approach was adopted and special attention was given to the verbal content of TED talks in order to explore ways in which academics make use of language to achieve their professional objectives through this popularizing genre.

More precisely, a contrastive analysis was carried out by comparing a corpus of transcribed TED talks delivered by academics (hereafter TED_ac) to a corpus of university lecture transcripts (hereafter MICASE_lect) to observe whether, and if so to what extent, academics' discursive practices of self-presentation differ in these two settings. To this end, and on the basis of previous studies on the use of the pronoun we in the genre of the university lecture (Rounds 1987a, 1987b; Fortanet 2004), a quantitative analysis was first carried out to compare distributions of we in TED_ac and MICASE_lect, then a qualitative analysis followed to explore the discursive functions of $w e$ in the two corpora.

The TED_ac corpus covers a time span of ten years (2002-2012) and consists of talks which have been retrieved from the official TED website ${ }^{3}$. They are delivered by academics who either are native speakers of American English or have received their education in the US. Information about speakers was retrieved from both their TED speaker personal profiles available on the TED website and the speakers' personal or institutional web pages. It was not always possible to establish whether speakers had teaching assignments as well as doing research.

The MICASE_lect corpus, on the other hand, was drawn from the Michigan Corpus of Academic Spoken English (MICASE), a spoken-language corpus of 1.8 million tokens freely available on-line (Simpson et al. 1999), which consists of different academic speech events (e.g. lectures, colloquia, dissertation defenses, discussion sessions, etc.) recorded at the University of Michigan at Ann Arbor (see Table 1).

\begin{tabular}{cccc}
\hline & & & \\
corpora & speech events & tokens & time span \\
\hline TED_ac & 207 & 552,345 & $2002-2012$ \\
MICASE_lect & 35 & 348,005 & $1998-2001$ \\
& & & \\
\hline
\end{tabular}

Table 1. TED_ac and MICASE_lect corpora

Both MICASE and MICASE_lect cover a time span of four years (1998-2001). The difference in time spans between TED_ac and MICASE_lect (ten years for TED as opposed to four years for MICASE) is solely due to the availability of research materials and is not an intentional part of my research design. To the best of my knowledge, MICASE is, in fact, the only corpus of spoken academic American English available on-line.

2 As Burns et al. (2003) point out, science communication can address a variety of audiences (e.g. scientists, mediators, decision-makers, lay public) with different backgrounds, needs and expectations. Given their popularizing intent, TED talks are aimed at multiple audiences. There is no detailed record of the various TED audiences. However, an important distinction has to be drawn between those who attend a TED conference and those who watch TED talks online. In order to attend a TED conference it is necessary to apply for membership. Membership costs range from $\$ 8,500$ (for a standard annual membership) to $\$ 15,000$ (for a 5-year membership). Alternatively, TED talks can be watched for free via the TED website. In this respect, it can be argued that, whereas most of those attending a TED conference are likely to be entrepreneurs, people accessing TED talks via the Web represent a wider and far more heterogeneous public. The opportunity to address so many different audiences through TED talks justifies the interest of TED speakers in presenting themselves and their ideas on the TED stage and, undoubtedly, affects the way in which TED speakers design and structure their talks.

3 Source: <www.ted.com> (Last accessed: December 8 2014). 
The number of speakers in the two corpora is also different: 207 speakers for TED as opposed to 35 speakers for MICASE. However, by way of compensation, the two corpora do not differ too much in size, in that MICASE lectures are, on average, longer than TED talks.

\begin{tabular}{|c|c|c|c|c|}
\hline & \multicolumn{2}{|c|}{ MICASE_lect } & \multicolumn{2}{|c|}{ TED_ac } \\
\hline & 'hard' disciplines & 'soft' disciplines & 'hard' disciplines & 'soft' discipline \\
\hline speech events & 18 & 17 & 125 & 82 \\
\hline tokens & 167,680 & 180,325 & 332,224 & 220,121 \\
\hline
\end{tabular}

Table 2. MICASE_lect and TED_ac sub-corpora

TED talks are monologic speech events. For this reason, in order to increase the comparability between the two corpora, the MICASE lectures were collected according to the attributes "highly monologic" and "mostly monologic". This was made possible thanks to the MICASE interface $^{4}$, which allows us to select speech events on the basis of different contextual attributes (e.g. event type, speaker's role, interactivity rating). Besides, the transcripts of the MICASE lectures have been cleansed of all the parts that did not pertain to the instructor (e.g. questions from the students).

\begin{tabular}{|c|c|}
\hline 'Hard' science category & Disciplines \\
\hline $\begin{array}{c}\text { Biological } \\
\text { and Health Sciences }\end{array}$ & $\begin{array}{l}\text { Biology, Biochemistry, Dentistry, Genetics, } \\
\text { Immunology, Natural Resources, Neuroscience, } \\
\text { Nursing, Pathology, Pharmacy, Physiology, Public } \\
\text { Health }\end{array}$ \\
\hline $\begin{array}{l}\text { Physical Sciences } \\
\text { and Engineering }\end{array}$ & $\begin{array}{l}\text { Astronomy, Chemistry, Computer Science, } \\
\text { Engineering (all), Geology, Mathematics, Physics, } \\
\text { Statistics, Technical Communication }\end{array}$ \\
\hline 'Soft' science category & Disciplines \\
\hline $\begin{array}{l}\text { Social Sciences } \\
\text { and Education }\end{array}$ & $\begin{array}{l}\text { Anthropology, Business Administration, } \\
\text { Communication, Economics, Education, History, } \\
\text { Public Policy, Political Science, Psychology, Social } \\
\text { Work, Sociology, Urban and Regional Planning }\end{array}$ \\
\hline $\begin{array}{l}\text { Humanities } \\
\text { and Arts }\end{array}$ & $\begin{array}{l}\text { Area Studies (all), Architecture, Classics, } \\
\text { Comparative Literature, English, Fine Arts (all), } \\
\text { Foreign Languages, History of Art, Information and } \\
\text { Library Science, Linguistics, Philosophy, Women's } \\
\text { Studies }\end{array}$ \\
\hline
\end{tabular}

Table 3. Disciplinary categories in MICASE_lect and TED_ac

4 Source: $<$ http://quod.lib.umich.edu/cgi/c/corpus/corpus?c=micase;page=simple $>$ (Last accessed: January 24 2014). 
Furthermore, on the basis of four macro subject areas established by the authors of MICASE, both the TED_ac and MICASE_lect corpora were subdivided into two subcategories (see Table 2 ), separating the 'hard' disciplines from the 'soft' ones. In line with other studies on academic discourse (e.g. Hyland 2004b, 2005, 2010), dividing the 'hard' disciplines from the 'soft' ones was considered necessary in order to understand whether, and if so to what extent, changes in discourse in the two genres are also contingent on the type of discipline the speaker is dealing with. As shown in Table 3, each one of the four macro subject areas consists of a series of sub-disciplines. These are equally distributed in both MICASE_lect and TED_ac.

Among other genres (e.g. conference presentation, TV documentary), the genre which shares the highest number of features with TED is the university lecture, which is why it was chosen for comparison. In both contexts, an expert attempts to convey (specialized) content to an audience of (semi) lay people drawing on different semiotic modes (i.e. written, spoken, video and audio) within a mostly monologic speech event (Caliendo/Compagnone 2014).

However, a substantial difference between lectures and TED talks which cannot be overlooked is that while in university lectures the instructor's main concern is to train a group of students who know that they will be assessed at the end of the course, in TED talks academics present and promote their research, also in an attempt to meet the expectations of an audience willing to be entertained while listening to riveting stories and encountering inspiring and innovative ideas.

Against this backdrop, particular consideration in this paper is given to changes in the ways in which academics represent themselves discursively in the shift from the environment of the classroom to that of TED ${ }^{5}$. This is seen as a crucial step to highlighting differences between the communicative purposes of TED talks and university lectures.

To pursue this aim, attention is focused on the distribution and use of first and second person pronouns in the two settings under scrutiny. As Rounds (1987a: 14) points out, "the relationship between language and context is most evident in the deictic system" while pronouns lie "at the intersection of the grammatical and pragmatic subsystem of language", thus playing a fundamental role in the representation of both the speaker and the addressee.

In the analysis that follows, particular emphasis is placed on the use of the pronoun we, which proved to be significantly more frequent in TED_ac than in MICASE_lect (see Section 4.1). The pronoun we is quite problematic in that, as Pennycook (1994: 175) points out, "[it] is always [...] a pronoun of solidarity and of rejection, of inclusion and exclusion". In claiming both authority and commonality, the pronoun we "also constructs a welyou or a welthey dichotomy. Thus, these two pronouns must always be understood with reference to other assumptions about who is being defined as the we from which the you and the they differ" (Pennycook 1994: 176).

On the basis of previous research on the use of the pronoun we in university lectures (Rounds 1987a, 1987b; Fortanet 2004), its frequency in TED talks as well as its referents and discourse functions compared to those found in university lectures will be examined. Specifically, the following two inquiry points formed the basis of the analysis:

- Does the pronoun we perform similar discourse functions in the two pragmatic contexts under scrutiny?

- Is there a correlation between use and distribution of we in the two genres and the type of discipline ('hard' vs. 'soft') the speaker is dealing with?

5 Speakers in the MICASE lect corpus differ from those in the TED ac corpus. Here, the term 'shift' is, in fact, used figuratively to refer to a process of 'reconceptualization' of academic discourse via the web-mediated genre of TED talks. Looking at the way the same speaker performs in the two contexts under scrutiny would have undoubtedly offered deep insight into the study of popularization as a phenomenon of 'recontextualization'. However, it was unfortunately not possible to retrieve transcripts of the lectures TED speakers deliver in their home institutions. Nevertheless, a contrastive analysis of MICASE university lectures and TED talks was still thought useful for highlighting some of the distinguishing features of TED as a new genre. 
To address these questions, both quantitative and qualitative searches were carried out using computer software AntConc 3.4.1 (Anthony, 2014) to obtain and compare word lists, concord lists and keyword lists from the two corpora under investigation. Furthermore, although the exploration of the TED website (and of the communicative purposes of the TED website authors) is outside the scope of the present study, consideration was also briefly given to ways in which the website is organized in order to contextualize the results of the linguistic analysis.

\section{Results and discussion}

The present paper follows a two-step research design, in which an exploratory quantitative investigation is followed by a more in-depth qualitative analysis. More precisely, emphasis is first placed, in section 4.1, on the frequency of first and second person pronouns in MICASE_lect and TED_ac. In section 4.2, attention is then paid to the referents of the pronoun we and its discourse functions in the two corpora.

\subsection{Frequency of first and second person pronouns in MICASE_lect and TED_ac}

In a study based on the analysis of a corpus of five lectures recorded at the University of Michigan and that related to the discipline of mathematics, Rounds (1987a, 1987b) points out that speakers tend to use the pronoun we more frequently than the pronouns $I$ and you. On the other hand, by means of a search using a sub-corpus of lectures and colloquia drawn from MICASE ${ }^{6}$, Fortanet (2004) comes up with opposite results: the pronouns $I$ and you are more frequent than we. Both Rounds and Fortanet's results are shown in Table 4.

\begin{tabular}{ccccc}
\hline & \multicolumn{2}{c}{ Rounds' corpus } & \multicolumn{2}{c}{ Fortanet's corpus } \\
\cline { 2 - 5 } Pronouns & Occurrences & Frequency ptw & Occurrences & Frequency ptw \\
\hline \multirow{2}{*}{ I } & 301 & 11.5 & 13,827 & 17.9 \\
me & 26 & 1 & 1,180 & 1.5 \\
we & 907 & 34 & 7,450 & 9.7 \\
us & 35 & 1 & 610 & 0.8 \\
let's & 92 & 3.5 & 644 & 0.8 \\
you & 335 & 12.5 & 16,000 & 20.7 \\
\hline
\end{tabular}

Table 4. Frequency of first and second person pronouns in Rounds and Fortanet's corpora (Fortanet 2004)

As far as the results found in Fortanet (2004) are concerned, it must be noted that while the gap between you and we is statistically relevant $(\mathrm{p}<0.05 \%)$, the opposite is true when comparing $I$ to we. However, by means of a second search using an alternative corpus of three different speech events ${ }^{8}$ related to mathematics - the discipline of Rounds' corpus of lectures - Fortanet (2004) points out that the pronoun $I$ is significantly more frequent than we (as well as than you). Against this background, she argues that "it is perhaps not the disciplinary and instructional character of mathematics that encourages a greater employment of $w e$ " and that "an explanation for Rounds' anomalous results - in terms of the bigger MICASE picture - needs to be found elsewhere" (Fortanet 2004: 52).

6 The MICASE sub-corpus used by Fortanet (2004) and the one used for this study have been collected drawing on different criteria. While Fortanet merged together lectures and colloquia, the MICASE sub-corpus used for this study consists of lectures only. This might partly explain differences in results.

7 Per thousand words.

8 A lecture, a colloquium and a study group transcript. 
As stated above, one of the main purposes of this study was to compare a corpus of TED talks delivered by academics to a corpus of lectures drawn from MICASE. Nevertheless, before moving on to this, it is necessary to compare the results obtained using MICASE_lect (see Table 5) with those found in Rounds (1987a, 1987b) and Fortanet (2004). This comparison provides the grounds for further considerations.

\begin{tabular}{|c|c|c|c|c|c|}
\hline \multirow[b]{2}{*}{ Pronouns } & \multicolumn{2}{|c|}{ 'hard' science lectures } & \multicolumn{2}{|c|}{ 'soft' science lectures } & \multirow{2}{*}{$\begin{array}{c}\text { whole corpus } \\
\text { TOT }\end{array}$} \\
\hline & Occurrences & Frequency ptw & Occurrences & Frequency ptw & \\
\hline I & 1,925 & 11 & 2,511 & 14 & 12.7 \\
\hline me & 152 & 0.9 & 242 & 1.3 & 1.1 \\
\hline we & 1,855 & 11 & 1,473 & 8.1 & 9.5 \\
\hline us & 73 & 0.4 & 134 & 0.7 & 0.5 \\
\hline let's & 197 & 1.1 & 113 & 0.6 & 0.8 \\
\hline you & 3,359 & 20 & 3,717 & 20.6 & 20.3 \\
\hline
\end{tabular}

Table 5. Frequency of first and second person pronouns in MICASE_lect (348,005 tokens)

As shown in Table 5, in MICASE_lect both $I$ and you are more frequent than the pronoun we. However, in line with Fortanet's results, it must be pointed out that, unlike I, you (used both as subject and object) is significantly more frequent than we and its object related forms $(\mathrm{p}<0.05 \%)$.

Moreover, comparing the two subsections of the MICASE_lect corpus with each other, it turns out that while in the 'soft' subgroup the pronoun $I$ is more frequent than we, in the 'hard' subgroup both singular and plural first person pronouns almost show the same frequency rate. This seems to suggest that the use of first person pronouns within the genre of the university lecture depends, to an extent, upon the type of discipline the speech event relates to. Nevertheless, the gap between the occurrences of we and those of $I$ in the 'soft' subgroup of lectures did not prove to be statistically relevant ( $\mathrm{p}>0.05 \%)$. This means that the difference in the use of $w e$ and $I$ in the two subgroups is very likely to be due to chance alone.

Comparing the frequency of first and second person pronouns in MICASE_lect to that in TED ac (see Table 6), a difference catches the eye: we outnumbers $I$.

\begin{tabular}{cccccc}
\hline & \multicolumn{2}{c}{ 'hard' science talks } & 'soft' science talks & whole corpus \\
\cline { 2 - 5 } Pronouns & Occurrences & Frequency ptw & Occurrences & Frequency ptw & TOT \\
\hline \multirow{2}{*}{ I } & & & & & 13.4 \\
me & 4,504 & 13.5 & 2,967 & 2 & 13.5 \\
we & 554 & 1.6 & 446 & 13.8 & 16 \\
us & 5,806 & 17.4 & 3,045 & 2 & 1.9 \\
let's & 600 & 1.8 & 481 & 0.5 & 0.4 \\
you & 140 & 0.4 & 122 & 18 & 17.7 \\
\hline
\end{tabular}

Table 6. Frequency of first and second person pronouns in TED_ac $(552,345$ tokens)

Although the gap between we and $I$ is not statistically relevant, a keyword list of TED_ac, obtained by using MICASE_lect for comparison, confirmed the saliency of the pronoun we in TED 
ac. We is, in fact, the first keyword of the list with a highly reliable $p$-value (see Table 7), followed by its related forms our and us.

As is evident in Table 6, while in the 'hard' subcategory of TED_ac we ranks higher than $I$, in the 'soft' subcategory the two pronouns almost show the same frequency rate. However, the gap between the pronouns $I$ and we is not high enough to warrant the claim that in the 'hard' subsection the pronoun we is more frequently used than $I$.

\begin{tabular}{cccc}
\hline $\mathrm{N}$ & Keyword & Keyness & p-value \\
\hline 1 & we & 823.07 & 0.0000000000 \\
2 & our & 492.01 & 0.0000000000 \\
3 & us & 309.40 & 0.0000000000 \\
4 & universe & 251.79 & 0.0000000000 \\
5 & brain & 238.24 & 0.0000000000 \\
6 & to & 237.53 & 0.0000000000 \\
7 & my & 204.93 & 0.0000000000 \\
8 & going & 196.00 & 0.0000000000 \\
9 & years & 187.24 & 0.0000000000 \\
10 & people & 180.83 & 0.0000000000 \\
11 & DNA & 180.48 & 0.0000000000 \\
12 & ok & 179.51 & 0.0000000000 \\
13 & thank & 166.27 & 0.0000000000 \\
14 & human & 154.82 & 0.0000000000 \\
15 & love & 137.36 & 0.0000000000 \\
& & & \\
\hline
\end{tabular}

Table 7. TED_ac keyword list

Apparently, in both MICASE lectures and TED talks, the frequency in the use of the first and second person pronouns is not significantly affected by the subject area of the speaker. Moreover, evidence suggests that academics speaking at TED make greater use of the pronoun we than do university lecturers. This is the reason why it was considered useful to investigate further the use of we in TED talks and university lectures.

\subsection{Referents and discourse functions of $w e$ in MICASE_lect and TED_ac}

Besides the traditional distinction between inclusive and exclusive uses of the pronoun we (Haas 1969; Spiegelberg 1973; Pennycook 1994; Kuo 1998; Biber et al. 1999), depending on whether or not the hearer is being referred to, Rounds (1987a) establishes some "semantic remappings" for the pronoun we:

a) we in contexts in which $I$ (i.e. the speaker) is more specifically marked (e.g. "we said that..."; the teacher is referring to some information which has already been given);

b) we in contexts where the actual sole referent is the hearer (e.g. "I want to look at some of

9 According to Baker (2006: 125), "a p-value (a number between 0 and 1) indicates the amount of confidence that we have that a word is key due to chance alone - the smaller the p-value, the more likely that the word's strong presence in one of the sub-corpora is not due to chance but a result of the author's (conscious or subconscious) choice to use that word repeatedly". 
the problems we had for today...");

c) we having as its actual referent 'anyone who does calculus' (e.g. "we [mathematicians] call that number...").

To these, Fortanet (2004: 54-59) adds the following categories:

d) reported-speech we having as its referent a larger group of people (including the reported speaker and excluding the speaker and the hearer) (e.g. "this is what a faculty member told me. We hardly ever discussed anything");

e) we having as its referent a larger group of people (including speaker + audience) (e.g. “... humans have come up with $\mathrm{m}$ - terms of how to, acquire those things that they need, that we need...");

f) we having as its referent an indefinite you or one (e.g. "...they start doing this again, which would be like if we were to cough extendedly or hiccup extendedly");

g) we having as its referent they.

As stated above, drawing on a qualitative analysis, all these uses of the pronoun we were manually researched by carefully examining every occurrence of this pronoun in the MICASE_lect and TED_ac corpora. Interpreting the various referential uses of the pronoun we in the two corpora was not an easy task. In some cases instances of we were ambiguous and could not be classified. Following the same procedure carried out for the quantitative part, before moving on to the comparison between MICASE_lect and TED_ac, the results obtained by looking at MICASE_lect are compared to those found in Rounds (1987a) and Fortanet (2004). The referents of we in MICASE_lect are illustrated in Table 8.

\begin{tabular}{|c|c|c|c|c|c|}
\hline \multirow[b]{2}{*}{ Referents } & \multicolumn{2}{|c|}{ 'hard' science lectures } & \multicolumn{2}{|c|}{ 'soft' science lectures } & \multirow{2}{*}{$\begin{array}{c}\text { whole corpus } \\
\text { TOT } \\
\end{array}$} \\
\hline & Occ. & Freq. phw ${ }^{10}$ & Occ. & Freq. phw & \\
\hline I & 573 & 31.2 & 282 & 19.3 & 26 \\
\hline you & 224 & 12.2 & 239 & 16.4 & 14 \\
\hline speaker + hearer & 135 & 7.4 & 170 & 11.6 & 9.2 \\
\hline $\begin{array}{c}\text { speaker }+ \\
\text { other people }\end{array}$ & 83 & 4.5 & 50 & 3.4 & 4 \\
\hline $\begin{array}{l}\text { larger group of people in } \\
\text { reported direct speech } \\
\text { (including the reported } \\
\text { speaker) }\end{array}$ & 49 & 2.6 & 140 & 9.6 & 5.7 \\
\hline $\begin{array}{c}\text { larger group of people } \\
\text { (including speaker }+ \\
\text { hearer) }\end{array}$ & 64 & 3.5 & 64 & 4.4 & 4 \\
\hline indefinite you or one & 595 & 32.4 & 349 & 24 & 28.7 \\
\hline they & 28 & 1.5 & 39 & 2.7 & 2 \\
\hline Unclassified $^{11}$ & 21 & 1.1 & 41 & 2.8 & 2 \\
\hline false starts ${ }^{12}$ & 61 & 3.3 & 85 & 5.8 & 4.4 \\
\hline
\end{tabular}

Table 8. Referents of we in MICASE_lect

10 Per hundred words. 
In a corpus of four lectures used by Fortanet for her qualitative search, the pronoun we has as its main referent the category "larger group of people in reported direct speech (including the reported speaker)", this use being "always exclusive, since there is no logical link between the reported speaker and the audience" (Fortanet 2004: 57):

(1) $[\ldots]$ and when folks came in for their check up and they were about three (few) weeks away from their due date (people) would say now, you know we don't want you just waiting too long and going into labor so (as) we have to deliver you here. (Fortanet 2004; Lecture 4)

The second most frequent referent of we in Fortanet's corpus is "larger group of people (including speaker + audience)", used by the speaker "to involve the audience in what $\mathrm{s} / \mathrm{he}$ is saying" (Fortanet 2004: 57):

(2) [...] humans have come up with m-terms of how to, acquire those things that they need, that we need. (Fortanet 2004; Lecture 2)

In Fortanet's corpus the pronoun we is also often used to refer either to the speaker (as $I$ ) or to the audience (as you) or to both of them excluding other people. As shown in Table 8, unlike the results found in Fortanet, in MICASE_lect the most frequent referent of we is "indefinite you or one". Unsurprisingly, the impersonal use is more frequent in the hard lectures $(32.4 \%)$ than in the soft ones (24\%), where self-mention and speculation are far more tolerated. The second most frequent referent of $w e$ in MICASE_lect is $I(26 \%)$ through which "the speaker involves the students in actions s/he can only do" (Fortanet 2004: 58):

(3) $[\ldots]$ uh we ended last time with the beginnings of political unrest in the uh march of Sulla on Rome, very briefly. Uh but we wanna go and t- take a f- a few steps back uh before we continue with that story. (MICASE_lect, History)

(4) [...] what we're gonna do, in, today's lecture, is we're basically done with history, we're done with methods, and we're going on to biopsychology. (MICASE_lect, Psychology)

It is worth noting that, although in MICASE_lect speakers dealing with soft disciplines tend to use the pronoun $I$ more frequently than speakers dealing with hard disciplines (see Table 5), "we as $I^{\prime}$ ' is significantly more frequent in the hard lectures (31.2\%) than in the soft ones $(19.3 \%)$.

As far as the referents of we in TED_ac are concerned, the results are illustrated in Table 9:

11 A small number of occurrences of we in both MICASE_lect and TED_ac were ambiguous and could not be classified.

12 This category includes occurrences of we used by the speaker when they take time to formulate a complete sentence (e.g. we've seen a film and we've...we've read a lot about foraging bands). 


\begin{tabular}{|c|c|c|c|c|c|}
\hline \multirow[b]{2}{*}{ Referents } & \multicolumn{2}{|c|}{ 'hard' science talks } & \multicolumn{2}{|c|}{ 'soft' science talks } & \multirow{2}{*}{$\begin{array}{c}\text { whole corpus } \\
\text { TOT } \% \\
\end{array}$} \\
\hline & Occ. & Freq. phw & Occ. & Freq. phw & \\
\hline I & 124 & 2.2 & 46 & 1.6 & 1.9 \\
\hline you & 80 & 1.4 & 20 & 0.7 & 1.2 \\
\hline speaker + hearer & 132 & 2.3 & 71 & 2.4 & 2.4 \\
\hline $\begin{array}{c}\text { speaker }+ \\
\text { other people }\end{array}$ & 2,736 & 48.4 & 672 & 22.7 & 39.6 \\
\hline $\begin{array}{l}\text { larger group of people in } \\
\text { reported direct speech } \\
\text { (including the reported } \\
\text { speaker) }\end{array}$ & 148 & 2.8 & 388 & 13.1 & 6.3 \\
\hline $\begin{array}{l}\text { larger group of people } \\
\text { (including speaker }+ \\
\text { hearer) }\end{array}$ & 488 & 8.6 & 542 & 18.3 & 11.9 \\
\hline indefinite you or one & 1,901 & 33.7 & 1,191 & 40.3 & 35.9 \\
\hline they & 8 & 0.1 & 15 & 0.5 & 0.3 \\
\hline Unclassified $^{13}$ & 24 & 0.4 & 10 & 0.3 & 0.4 \\
\hline false starts ${ }^{14}$ & 8 & 0.1 & 4 & 0.1 & 0.1 \\
\hline
\end{tabular}

Table 9. Referents of we in TED_ac

Unlike MICASE_lect, in TED_ac the most frequent referent of the pronoun we is "speaker + other people" $(39.6 \%)$, followed by the referents "indefinite you or one" $(35.9 \%)$ and "larger group of people (including speaker + hearer)" $(11.9 \%){ }^{14}$

Besides its referents, Fortanet also looked at the discourse functions played by we in university lectures and it turned out that those found in her corpus could be grouped into two main categories: "metadiscourse function" and "representation-of-group function". The first function includes uses of we as $I$ and we as you, which serve to guide the hearer through the speech event:

(5) We're gonna talk a little bit about the development of vitamin E rich plants (MICASE_lect, Biology)

(6) Make sure that we all, sort of understand what Darwin's Theory of Evolution was about (MICASE_lect, Psychology)

(7) As we can see the theme of today is the emergence of the monarchy (MICASE_lect, History)

The second discourse function highlighted by Fortanet includes uses of the pronoun we with referents "speaker + hearer", "speaker + other people", "larger group of people in reported speech", "larger group of people (including speaker + hearer)" and "we as they". Table 10 compares the discourse functions of we found in MICASE_lect with those found in TED_ac.

13 A small number of occurrences of we in both MICASE_lect and TED_ac were ambiguous and could not be classified.

14 This category includes occurrences of we used by the speaker when they take time to formulate a complete sentence (e.g. we've seen a film and we've...we've read a lot about foraging bands). 


\begin{tabular}{ccccc}
\hline & \multicolumn{2}{c}{ MICASE_lect } & \multicolumn{2}{c}{ TED_ac } \\
\cline { 2 - 5 } Discourse functions & Occurrences & Freq. ptw & Occurrences & Freq. ptw \\
metadiscursive & 1,318 & 3.8 & 270 & 0.4 \\
representation of groups & 822 & 2.3 & 5,200 & 9.4 \\
indefinite we & 67 & 0.2 & 23 & 0.04 \\
unclassified & 22 & 0.1 & 34 & 0.06 \\
\hline
\end{tabular}

Table 10. Discourse functions of $w e$ in MICASE_lect and TED_ac

There is a striking difference between the two corpora: while in MICASE_lect we is more frequently used metadiscursively (see examples (5)-(7) above), in TED_ac it is predominantly used for the representation of groups of people ( 9.4 occurrences per thousand words). Although the gap between metadiscursive and representational uses of we in MICASE_lect is not particularly high, in TED_ac the pronoun we used with a "representation of groups" function is significantly more frequent than in MICASE_lect. ${ }^{15}$

\begin{tabular}{cccc}
\hline Groups & 'hard' science talks & 'soft' science talks & whole corpus \\
\hline $\begin{array}{c}\text { speaker + hearer } \\
\text { speaker + other people }\end{array}$ & 3.7 & $\%$ & TOT \\
$\begin{array}{c}\text { larger group of people } \\
\text { in reported direct speech }\end{array}$ & 78 & 39.8 & 65.5 \\
$\begin{array}{c}\text { larger group of people } \\
\text { (including speaker + hearer) }\end{array}$ & 4.2 & 22.9 & 10.3 \\
they & 13.9 & 32.1 & 19.9 \\
& 0.2 & 0.8 & 0.4 \\
\hline
\end{tabular}

Table 11. Representation of groups in TED_ac

As shown in Table 11, the most frequent group represented in TED_ac is "speaker + other people" $(65.5 \%)$. Besides, it is worth pointing out that this use of we is remarkably more frequent in the

15 In order to see whether the observed difference in proportions of the representation-of-group we in MICASE_lect and TED ac (2.3 vs. 9.4) was statistically significant, a chi-square test was performed by comparing the observed relative raw frequencies of $w e$ used to represent groups in MICASE_lect and TED_ac (i.e. 822 vs. 5,200) with the frequencies one would expect if there were no difference in proportions in the two corpora (i.e. 2,088 vs. 3,314). The chi-square test statistic was obtained by using the following formula (where $\mathrm{O}=$ number of observed frequencies and $\mathrm{E}=$ number of expected frequencies):

$$
\chi^{2}=\sum \frac{(O-E)^{2}}{E}
$$

Once the chi-square test statistic was computed, the result was compared with a set of chi-squared distribution values on one degree of freedom. Comparison between the obtained chi-square test statistic $\left(\chi^{2}=1851.9\right)$ and the chi-square distribution on one degree of freedom (10.83) showed that the difference in proportions is statistically significant given a highly reliable $\mathrm{p}$-value $(\mathrm{p}<0.001)$. The test statistic obtained allows us to reject (at the $0,001 \%$ level) the null hypothesis, i.e., the possibility that the observed numerical difference in the use of the representation-of-group we in MICASE_lect and TED_ac is due to chance alone. 
hard subsection (78\%). This may be accounted for by the fact that team work is more common a practice in the hard science domains:

(8) A FOXO is a protein that we found in these little, round worms to affect lifespan, and here it affects lifespan in people. So we've been trying in our lab now to develop drugs that will activate this FOXO cell using human cells now in order to try and come up with drugs that will delay aging and age-related diseases. (TED, Biochemistry)

(9) And so, with funding from the Bosack-Kruger Foundation, I got a lot of strains from these different countries and we measured their toxin production in the lab. And we found that in Chile - within two months of the invasion of Peru you had strains entering Chile - and when you look at those strains, in the very far left-hand side of this graph, you see a lot of variation in the toxin production. (TED, Biology)

(10) One of the things that we've developed in the lab - we've developed several vehicles - is what we believe is the world's first autonomously drifting car. (TED, Engineering)

(11) We have a tool that actually helps us out in this study. (TED_ac, Astronomy)

(12) [...] and then we did a series of calculations, and what we were able to show is that these mantis shrimps have to have a spring. (TED_ac, Biology)

As illustrated in examples (8)-(12) above, the pronoun we is often used by academics in TED_ac to illustrate their own and their groups' research aims, methodologies and discoveries, thus aligning themselves with a group of colleagues and at the same time building up their image as experts. This can be considered the most significant finding as far as the use of the pronoun we in TED_ac is concerned. By aligning themselves to a group of experts - though excluding the lay hearer - speakers are more likely to acquire a degree of credibility in the eyes of their audience. As Hyland points out, by "laying stress on their membership, their joint affiliation to a community-situated pursuit of knowledge is an important way that writers give persuasive weight to their texts" (2004a: 99). In this way not only do academics at TED legitimize the information conveyed, they also seem to place emphasis on their authority, which students in the classroom situation are more likely to take for granted.

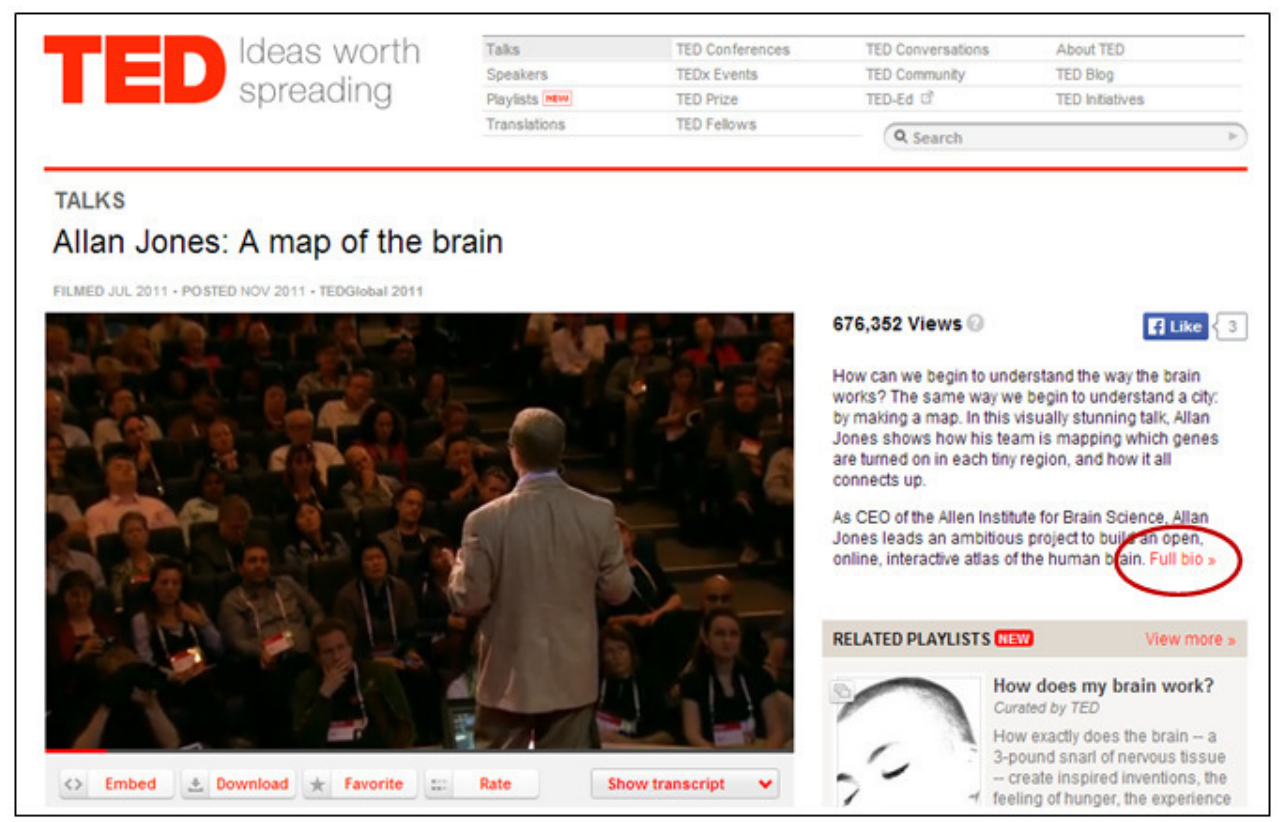

Figure 1. Allan Jones: A map of the brain (www.ted.com) 


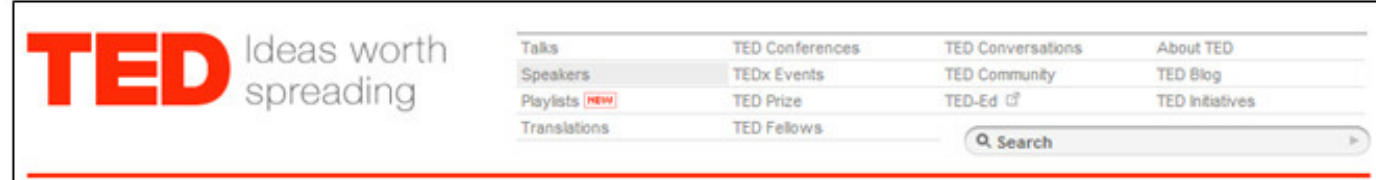

Speakers Allan Jones: Brain scientist
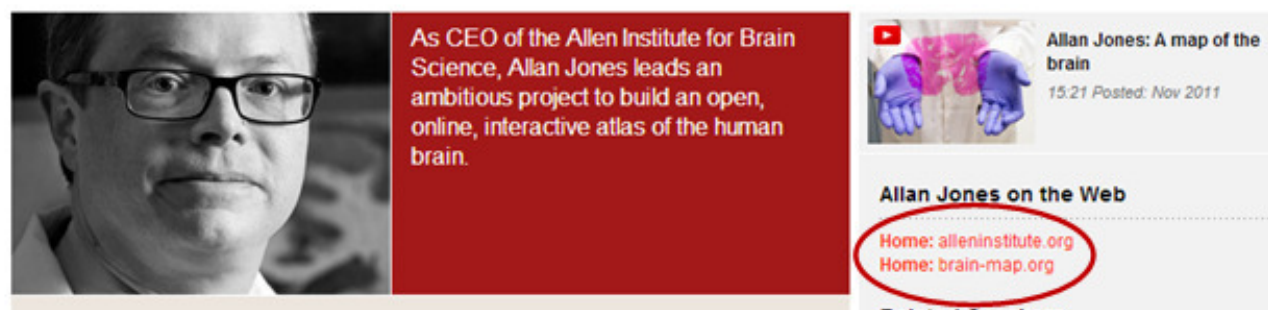

Why you should listen to him:

The Allen Institute for Brain Science - based in Seattle, kickstarted by Microsoft co-founder Paul Allen - has a mission to fuel discoveries about the human brain by building tools the entire scientific community can use. As CEO, one of Allan Jones' first projects was to lead the drive to create a comprehensive atlas of the brain of a mouse. Flash fonward to April 2011 When the Allen Institute announced the first milestone in its online interactive attas of the human brain, showing the activity of the more than 20,000 human genes it contains. If sased Related Speakers

Events

Figure 2. Allan Jones TED profile (www.ted.com)

Against this background, a tendency of the TED format to emphasize the expertise of the speaker can also be detected if one looks at the way the TED website is organized-paying attention to the way web-users, and not the co-present audience, are addressed. As shown in Figure 1, besides the video recording of the talk, on the same page one also finds a link, "Full bio" (in the column to the right, circled in red), which leads to a page providing information about the speaker (Figure 2). Here, in addition to a list of motivations "why you should listen to him/her", a series of links (in the column to the right, circled in red) to external web pages related to the expert are provided. In the Full-bio page dedicated to Allan Jones, for instance, one of the two links leads to the official web page of the Allen Institute for Brain Science (Figure 3), whose CEO is Allan Jones (Figure 4)

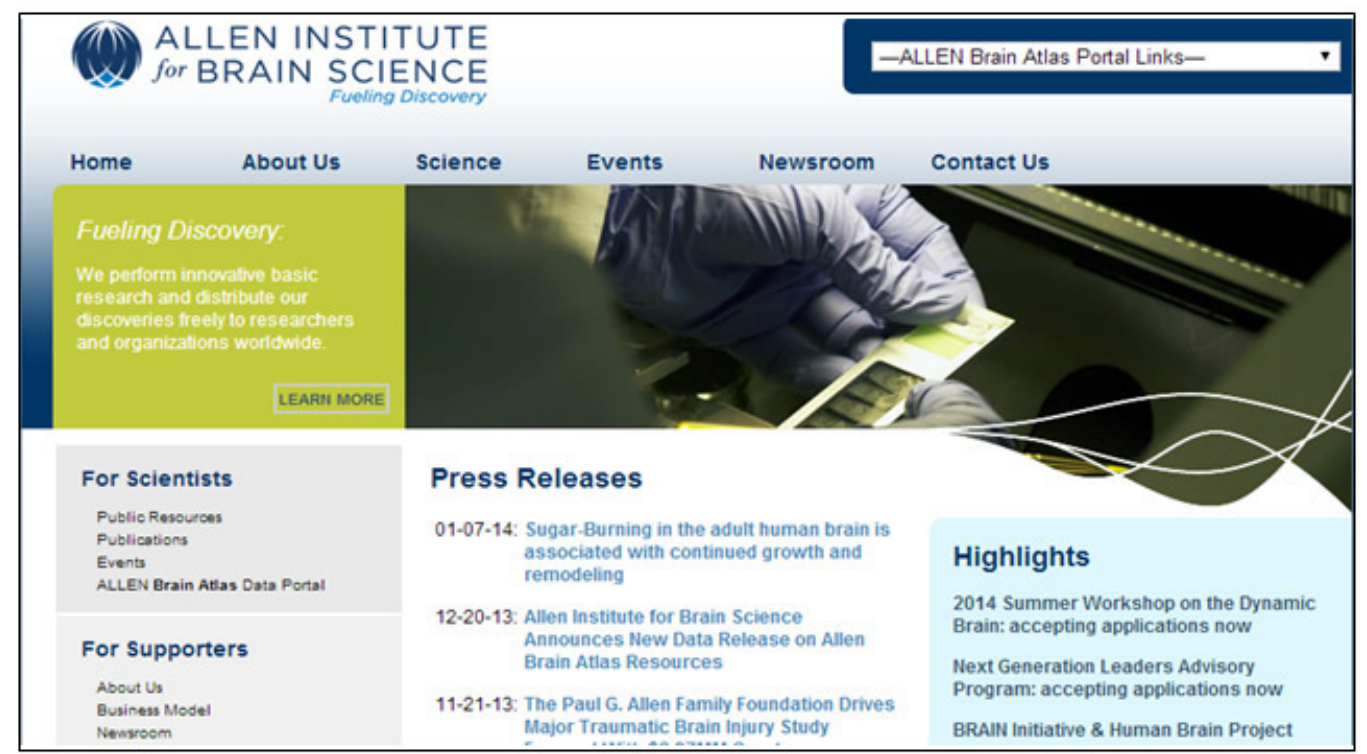

Figure 3. Allen Institute for Brain and Society official website 


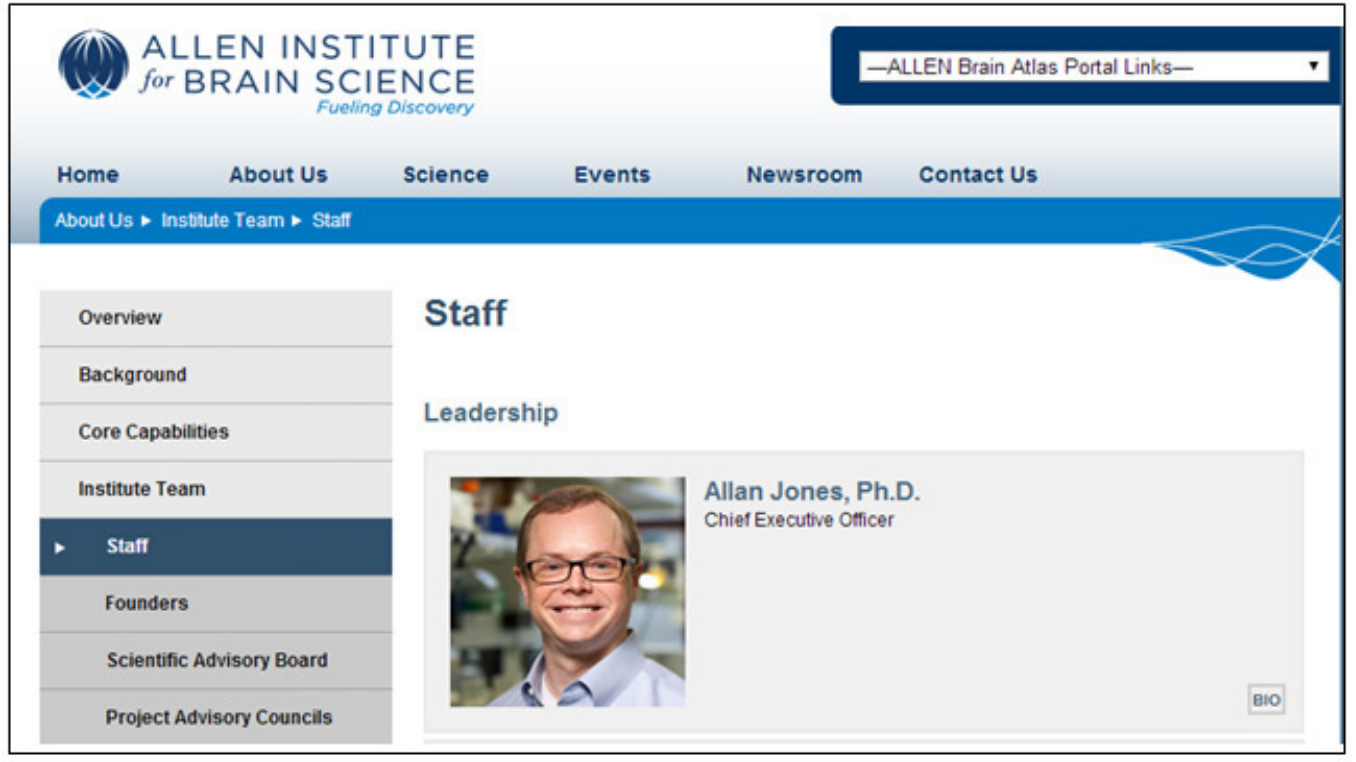

Figure 4. Allan Jones AIBS profile

Another example is illustrated in Figure 5. Here one of the external links leads to the personal profile of David Angus on the official website of the University of Southern California (Figure 6).

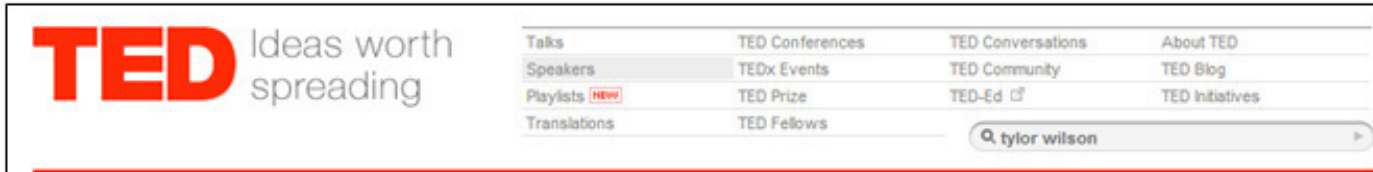

\section{Speakers David Agus: Cancer Doctor}

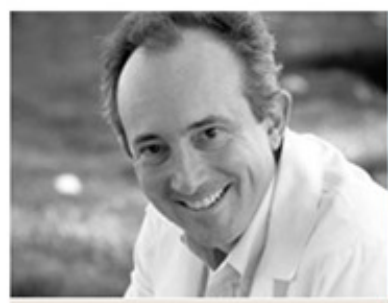

Athough a highly-accomplished

conventional doctor, David Agus has

embraced the future of medicine and is

constantly exploring ways that new

technologies can help in the fight

against cancer

Why you should listen to him:

David Agus is a medical doctor and a Professor of Medicine at the University of Southern

California. However, he is also the founder of a couple of game-changing medical initiatives.

In 2006, he co-founded Navigenics with Dietrich Stephan, Ph.D. to form a company that would

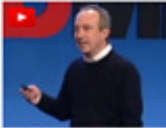

David Agus: A new strategy

in the war on cancer

23.44 Posted: Feb 2010

David Agus on the Web

Website: Navigenics.com

Homepage: Profle at USC

\section{Related Speakers}

Siegtried Woldhei

Bruce Aytward

Deborah Rhodes

Shatti Mather

Figure 5. David Agus TED profile (www.ted.com) 


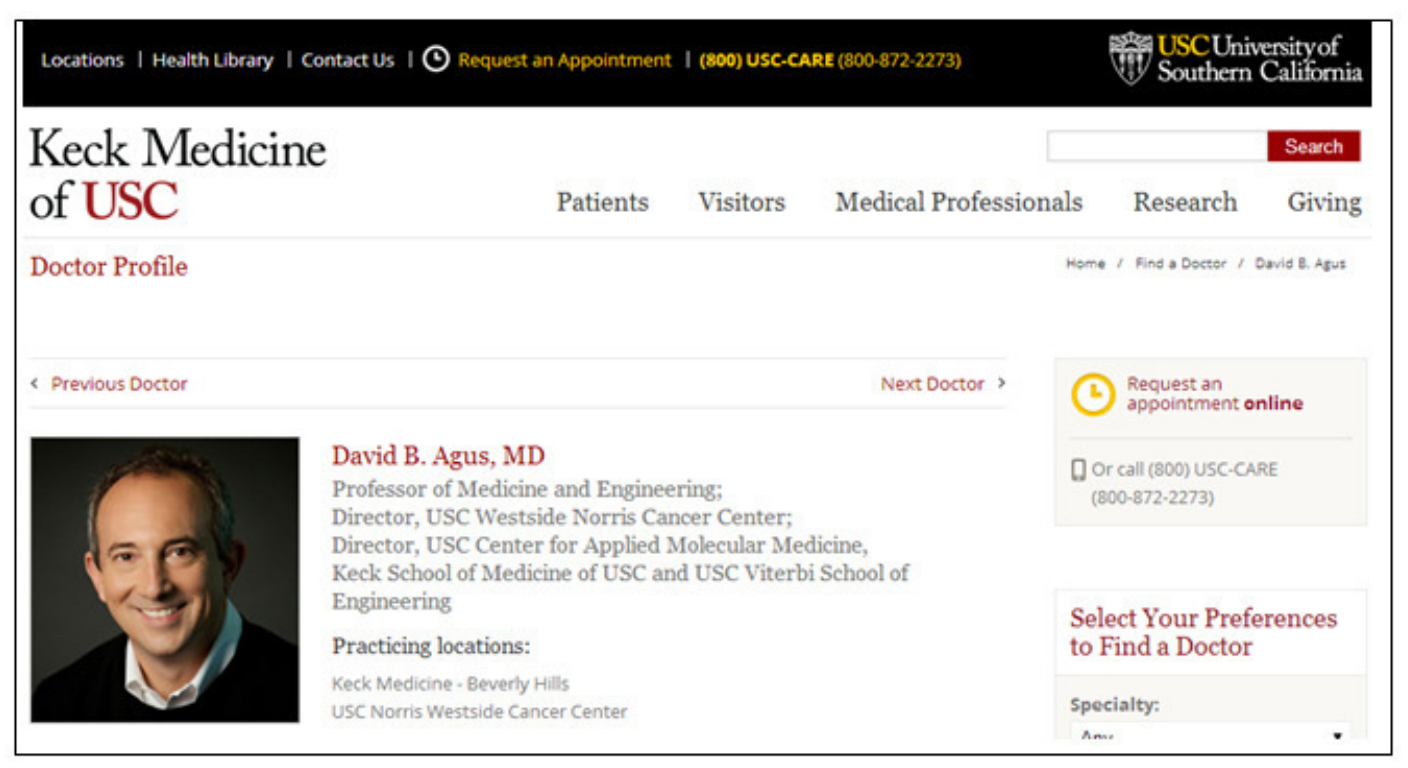

Figure 6. David Agus USC profile

The external web pages, like those shown in Figures 3, 4 and 6, work as extensions of the TED web space. Interestingly enough, not only do these external web pages contribute to the discursive construction of the speaker's identity as expert, they also serve to legitimate TED as a prestigious popularizing format and to confer reliability on the content proposed.

\section{Conclusions}

This study set out to investigate ways in which academic discourse is reconceptualized and recontextualized as a professional practice via the web-mediated popularizing genre of TED talks. More precisely, consideration was given to the way in which academics appropriate the TED stage to convey their "private intentions" (Bhatia 2012) - i.e. to build up their image as experts and promote their research - apart from training novices in their disciplines or merely informing mass audiences.

To pursue this aim, a corpus of transcribed TED talks delivered by academics (TED_ac) was put together and compared to a corpus of university lecture transcripts (MICASE_lect) to observe changes in language use associated with the transition of academics from the 'traditional' context of the university classroom to the new pragmatic setting of TED.

More specifically, attention was focused on the way in which academics represent themselves discursively in the setting of the university classroom and that of TED. To this end, special emphasis was placed on the distribution and use of the pronoun we in TED_ac and MICASE_lect. Moreover, by drawing a distinction between 'hard' and 'soft' sciences, distribution and uses of we in these two genres were also explored to understand whether, and if so to what extent, they are affected by the type of discipline the speaker is dealing with.

As far as the distribution of we in the two corpora is concerned, differences in frequencies were not high enough to warrant the claim that the distribution of $w e$ in university lectures and TED talks is affected by the discipline of the speaker. However, evidence suggests that this pronoun is significantly more frequent in TED_ac than in MICASE_lect.

As regards the referents of we, in MICASE_lect the most frequent referent of we is $I$ (i.e. the speaker). Such use enables the speaker to establish involvement with the students during the communicative exchange (Fortanet 2004: 58) (e.g. "what we're gonna do, in, today's lecture [...] we're going on to biopsychology"). In TED_ac instead the pronoun we has as its main referents 
"speaker + other people", thus excluding the audience (e.g. "we have a tool that actually helps us out in this study").

Differences in the reference scope of we in the two corpora correspond to differences in its discourse functions. In MICASE_lect, we is used mostly by academics with a "metadiscourse function", in order to guide the hearer through the speech event (Fortanet 2004). In TED_ac, we almost excludes the audience and is used by academics with a "representation-of-group function". This can be regarded as the most interesting finding as far as the use of we in TED_ac is concerned. By means of this deictic device, TED speakers mainly signal their belonging to a community or group of researchers and thereby build up their image as experts and place emphasis on their research activity. This use of we is particularly frequent in the hard-science talks, which may be accounted for by the fact that team work is more common a practice in the hard-science domains. From a sociological perspective, this finding supports the claim that "narratives of expertise are inherently collective" (Nowotny et al. 2001: 224). As Nowotny et al. (2001: 224) point out "the competence of the individual expert is inevitably limited. So competence must be derived from a collective pool of expertise" in order to get "the maximum degree of consensus".

Against this backdrop, person deixis proved to be a relevant linguistic phenomenon to examine, as it made it possible to highlight differences between the genre of academic TED talks and that of university lectures. Unlike university lectures, where classroom language is significantly message-oriented (Rounds 1987: 16), evidence suggests that - despite their declared informative purpose - TED talks work as an alternative pragmatic space where academics build up their image as experts and promote their and their groups' research and findings.

In spite of its language-centered approach, the present study has a marked sociological intent. Its aim was to provide empirical evidence to show that TED talks are a new pragmatic setting within which practices of knowledge dissemination evolve and get contaminated by other discursive practices, e.g. self-promotion, according to the conventions of today's "knowledge-based economy" (OECD 1996) as well as to the norms of a "professional culture" (Bhatia 2007; 2008; 2010; 2012). Here, the need on the part of the science system to establish direct contact both with the general public and with institutions is essential for the preservation of 'social prestige' and, increasingly, for the acquisition of research funds.

It is against this background that the theoretical framework of CGA - integrated with the theories of DA on the discursive construction of identity (e.g. Goffman 1981; Fairclough 1989; Pennycook 1994; De Fina 1995; Benwell/Stokoe 2006; De Fina et al. 2006) and the methods of corpus linguistics (Baker 2006; Baker et al. 2008) - has been found to be very useful for exploring the interdiscursive nature of academic TED talks and for showing, from a wider perspective, that popularization discourse is a complex phenomenon, involving processes of recontextualization (Calsamiglia 2003; Calsamiglia/van Dijk 2004) as well as of reconceptualization of academic discourse as a professional practice. On the TED stage, by aligning themselves with a group of expert researchers, academics present themselves as reliable spokespeople for a specific scientific community, while also promoting their research activities. In the light of this, it can be argued that the 'cult of personality' - intertwined with advertising purposes - has now become a common trend even in academia, as is also evidenced by other web-mediated genres (e.g. academia. edu, linkedin, twitter, facebook) used by academics to interact with their scientific communities as well as with the lay public.

The theoretical framework of CGA has so far been mainly drawn on for the investigation of professional discursive performance in legal and corporate contexts (e.g. Bhatia et al. 2008, 2009, 2010, 2012a, 2012b). Against this backdrop, the present study attempted to broaden the research application of CGA by focusing on an instance of academic discourse seen, for the first time, as an example of interdiscursive professional performance mediated through the Web and resulting from the combination of different communicative purposes (e.g. information provision and selfpromotion). 
In conclusion, with reference to TED talks, I would like to specify that every inference made about them in this study has to do with the way in which academic discourse is reconceptualized through this web-mediated genre. Nevertheless, from both a textual and a contextual view, TED is far more complex a format than that. TED gathers, in fact, different types of experts (not only academics) and serves the purposes of different stakeholders (e.g. the TED authors and curators). All this accounts for the interdiscursive nature of TED and is reflected, at a textual level, in the multimodal character of the format, which opens up a plethora of research venues and leaves space for a number of theoretical and methodological approaches as alternatives to those employed in this study.

\section{References}

Anthony, Laurence 2014: AntConc (Version 3.4.1.) [Computer Software]. Tokyo, Japan: Waseda University [online]. Available from http://www.laurenceanthony.net/

Anesa, Patrizia/Fage-Butler, Antoinette M. 2015: Popularizing Biomedical Information on an Online Health Forum. In Ibérica 29, 105-128.

Baker, Paul 2006: Using Corpora in Discourse Analysis. London: Continuum.

Baker, Paul/Gabrielatos, Costas/KhosraviNik, Majid/Krzyzanowski, Michal/McEnery, Tony/Wodak, Ruth 2008: A Useful Synergy? Combining Critical Discourse Analysis and Corpus Linguistics to Examine Discourses of Refugees and Asylum Seekers in the UK Press. In Discourse and Society, 19(3), 273-305.

Bakhtin, Mikhail 1986: Speech Genres and Other Late Essays. Austin, TX: University of Texas Press.

Bamford, Julia 2014: Rendering the Dismal Science More Lively: Popularizing Economics in English and Italian. In Bongo, Giancarmine/Caliendo, Giuditta (eds.), The Language of Popularization: Theoretical and Descriptive Models / Die Sprache der Popularisierung: Theoretische und Deskriptive Modelle. Bern: Peter Lang, 23-50.

Benwell, Bethan/Stokoe, Elizabeth 2006: Discourse and Identity. Edinburgh: EUP.

Bhatia, Vijay 1993: Analysing Genre: Language Use in Professional Settings. London: Longman.

Bhatia, Vijay 1997: Language of the Law. In Language Teaching 20, 227-234.

Bhatia, Vijay 2004: Worlds of Written Discourse: A Genre-Based View. London: Continuum.

Bhatia, Vijay 2007: Interdiscursivity in Critical Genre Analysis, Sympósio Internacional de Géneros Yextuais, Anais Proceedings, UNISUL, Tubarão SC (Brazil), 391-400.

Bhatia, Vijay 2008: Genre Analysis, ESP and Professional Practice. In English for Specific Purposes 27(2008), 161174.

Bhatia, Vijay 2009: Intertextual Patterns in English Legal Discourse. In Belcher, Diane (ed.), English for Specific Purposes in Theory and Practice. Ann Arbor, MI: University of Michigan Press, 186-204.

Bhatia, Vijay 2010: Interdiscursivity in Professional Communication. In Discourse \& Communication 21(1), 32-50.

Bhatia, Vijay 2012: Critical Reflections on Genre Analysis. In Ibérica 24, 17-28.

Bhatia, Vijay/Candlin, Christopher N./Engberg, Jan (eds.) 2008: Legal Discourse across Cultures and Systems. Hong Kong: HKU Press.

Bhatia, Vijay/Candlin, Christopher N./ Evangelisti, Paola (eds.) 2009: Legal Discourse in Multicultural Contexts. Bern: Peter Lang.

Bhatia, Vijay/Candlin, Christopher N./Gotti, Maurizio (eds.) 2010: The Discourses of Dispute Resolution. Bern: Peter Lang.

Bhatia, Vijay/Candlin, Christopher N./Gotti, Maurizio (eds.) 2012a: Arbitration Practice and Discourse: Issues, Challenges and Prospects. London: Ashgate Publishing.

Bhatia, Vijay/Garzone, Giuliana/Degano, Chiara (eds.) 2012b: Arbitration Awards: Generic Features and Textual Realisations. Newcastle upon Tyne: Cambridge Scholars Publishing.

Biber, Douglas/Johansson, Stig/Leech Geoffrey/Conrad, Susan/Finegan, Edward 1999: Longman Grammar of Spoken and Written English. Pearson Education, Harlow.

Bondi, Marina 2014: Connecting Science. Organizational Units in Specialist and Non-Specialist Discourse. In Bongo, Giancarmine/Caliendo, Giuditta (eds.), The Language of Popularization: Theoretical and Descriptive Models / Die Sprache der Popularisierung: Theoretische und Deskriptive Modelle. Bern: Peter Lang, 51-72.

Burns, Timothy/David O'Connor/Susan Stocklmayer 2003. Science Communication: A Contemporary Definition. In Public Understanding of Science 12, 183-202. 
Caliendo, Giuditta 2014a: Introduction. In Bongo, Giancarmine/Caliendo, Giuditta (eds.), The Language of Popularization: Theoretical and Descriptive Models/Die Sprache der Popularisierung: Theoretische und Deskriptive Modelle. Bern: Peter Lang, 7-19.

Caliendo, Giuditta 2014b: The Popularization of Science in Web-Based Genres. In Bongo, Giancarmine/Caliendo, Giuditta (eds.), The Language of Popularization: Theoretical and Descriptive Models/Die Sprache der Popularisierung: Theoretische und Deskriptive Modelle. Bern: Peter Lang, 101-132.

Caliendo, Giuditta/Compagnone, Antonio 2014: Expressing Epistemic Stance in University Lectures and TED Talks: A Contrastive Corpus-based Analysis. In Lingue e Linguaggi 11(2014), 105-22.

Calsamiglia, Helena 2003: Popularization Discourse. In Discourse Studies 5(2), 139-146.

Calsamiglia, Helena/López Ferrero, Carmen 2003: Role and Position of Scientific Voices: Reported Speech in the Media. In Discourse Studies 5(2), 147-173.

Calsamiglia, Helena/van Dijk, Teun 2004: Popularization Discourse and the Knowledge about the Genome. In Discourse and Society 15(4), 369-389.

Candlin, Christopher N./Maley Yon 1997: Intertextuality and Interdiscursivity in the Discourse of Alternative Dispute Resolution. In Gunnarsson, B-L/ Linnel, P./ Nordberg, B. (eds.) The Construction of Professional Discourse. London: Longman, 201-222.

Ciapuscio, Guiomar E. 2003: Formulation and Reformulation Procedures in Verbal Interactions between Experts and (Semi) Laypersons. In Discourse Studies 5(2), 207-233.

Compagnone, Antonio 2014: Knowledge Dissemination and Environmentalism: Exploring the Language of TED Talks. In Chiavetta, Eleonora/Sciarrino, Silvana/Williams, Christopher (eds.), Popularisation and the Media. Bari: Edipuglia, 7-25.

De Fina, Anna 1995: Pronominal Choice, Identity and Solidarity in Political Discourse. In Text - Interdisciplinary Journal for the Study of Discourse, 15(3), 379-410.

De Fina, Anna/Shiffrin, Deborah/Bamberg, Michael 2006: Discourse and Identity. Cambridge: CUP.

Fairclough, Norman 1989: Language and Power. London: Longman.

Fairclough, Norman 1992: Language and Social Change. Cambridge: Polity Press.

Fairclough, Norman 1995: Critical Discourse Analysis: The Critical Study of Language. London: Longman.

Fortanet, Inmaculada 2004: The Use of 'we' in University Lectures: Reference and Function. In English for Specific Purposes 23, 45-66.

Foucault, Michel 1981: The Order of Discourse, in Young, R. (ed.) Untying the Text: A Post-Structuralist Reader. London: Routledge, 51-78.

Garzone, Giuliana 2006: Perspectives on ESP and Popularization. Milano: CUEM.

Garzone, Giuliana 2014: News Production and Scientific Knowledge: Exploring Popularization as a Process. In Bongo, Giancarmine/Caliendo, Giuditta (eds.), The Language of Popularization: Theoretical and Descriptive Models / Die Sprache der Popularisierung: Theoretische und Deskriptive Modelle. Bern: Peter Lang, 73-107.

Goffman, Erving 1981: Footing. In Goffman, Erving (ed.), Forms of Talk. Philadelphia, PA: University of Pennsylvania Press, 124-159. (First published in Semiotica 25 (1979): 1-29).

Gülich, Elisabeth 2003: Conversational Techniques Used in Transferring Knowledge between Medical Experts and Non-Experts. In Discourse Studies 5(2), 235-263.

Haas, Mary R. 1969: 'Exclusive' and 'Inclusive': A Look at Early Usage. In International Journal of American Linguistics 35, 1-6.

Hyland, Ken 1998: Hedging in Scientific Research Articles. Amsterdam: Benjamins.

Hyland, Ken 2004a: A Convincing Argument: Corpus Analysis and Academic Persuasion. In Connor, Ulla/Upton, Thomas (eds.), Discourse in the Professions, John Benjamins, Amsterdam, 88-112.

Hyland, Ken 2004b: Disciplinary Discourses: Social Interactions in Academic Writing. Michigan: University of Michigan Press.

Hyland, Ken 2005: Stance and Engagement: A Model of Interaction in Academic Discourse. In Discourse Studies 7(2), 173-192.

Hyland, Ken 2009: Academic Discourse. English in Global Contexts. London: Continuum.

Hyland, Ken 2010: Constructing Proximity: Relating to Readers in Popular and Professional Science. In Journal of English for Academic Purposes 9, 116-127.

Kristeva, Julia 1980: Word, Dialogue and Novel. In Kristeva, J. (ed.), Desire in Language. Oxford: Blackwell, 64-91. 
Kuo, Chih-Hua 1998: The Use of Personal Pronouns: Role Relationships in Scientific Journal Articles. In English for Specific Purposes 20, 121-138.

Luey, Beth 2010: Expanding the American Mind. Massachusetts: University of Massachusetts Press.

Nowotny, Helga/Scott, Peter/Gibbons, Michael 2001: Re-Thinking Science. Knowledge and the Public in an Age of Uncertainty. Cambridge: Polity Press.

Nwogu, K. N. 1991. The Structure of Science Popularizations: a Genre Analysis Approach to the Schema of Popularized Medical Text. English for Specific Purposes 10, 111-118.

OECD. 1996. The Knowledge-Based Economy. OECD. Paris.

Pennycook, Alaster 1994: The Politics of Pronouns. In ELT Journal 48, 173-178.

Rounds, Patricia 1987a: Multifunctional Personal Pronoun Use in an Educational Setting. In English for Specific Purposes $6,13-29$.

Rounds, Patricia 1987b: Characterizing Successful Classroom Discourse for NNS Teaching Assistant Training. In TESOL QUARTERLY 21(4), 643-671.

Scotto di Carlo, Giuseppina 2014: The Role of Proximity in Online Popularizations: The Case of TED Talks. In Discourse Studies 16(5), 591-606.

Simpson Rita C./Briggs Sarah L./Ovens Janine/Swales, John M. 1999: The Michigan Corpus of Academic Spoken English. Ann Arbor, MI: The Regents of the University of Michigan [online]. <http://quod.lib.umich.edu/cgi/c/corpus/ corpus?page $=$ home; $c=$ micase $; c c=$ micase $>$ Last accessed: January 242014.

Spiegelberg, Herbert 1973: On the Right to Say “we’: A Linguistic and Phenomenological Analysis”. In G. Psathas (ed.) Phenomenological Sociology. New York: Wiley, 129-156.

Swales, John M. 1990: Genre Analysis: English in Academic Research and Writings. Cambridge University Press: Cambridge.

Swales, John M. 2004: Research Genres. Cambridge: Cambridge University Press 